\title{
REMOTE DETECTION OF RAGWEED (AMBROSIA ARTEMISIIFOLIA L.)
}

\author{
Ivan PLAŠČAK, Mladen JURIŠIĆ, Ante ŠILJEG, Lazar JEFTIĆ, Domagoj ZIMMER, Željko BARAČ
}

\begin{abstract}
The paper presents the contemporary findings of remote sensing regarding the control of common ragweed on agricultural land. The two-year research was performed in co-operation with the company Ciklonzacija Ltd., Serbia. The remote sensing process starts with the collection of images captured by several types of cameras equipped with special filters. Images are obtained by modified cameras mounted on helicopters, drones, and airplanes. Next, a special software is used to produce maps based on the obtained images that show the level of weed spread on agricultural land, illegal waste dumping areas, and other uncultivated areas, i.e. the areas that are potential sources of ragweed spread. The maps have a considerable economic benefit when mapping agricultural, wood, and other areas. Moreover, they reduce the use of human resources, and increase the capacity of data acquisition as well as the accuracy of the model of weed spread and its control.
\end{abstract}

Keywords: GIS; ragweed; remote detection; remote exploration; weeds

\section{INTRODUCTION}

Ambrosia artemisiifolia L. from the Asteraceae family, known as common ragweed, annual or low ragweed, is an annual weed. Due to its competitiveness, it causes direct agricultural losses. In addition, its pollen is a strong allergen and has an indirect negative effect. Thus, ragweed is cited as the most important weed nowadays [1-5]. It has been introduced from the North America to Europe [6,7]. There are about twenty species of ragweed in Europe, with the common ragweed (Ambrosia elatior, Ambrosia artemisifolia) being the most dispersed. It has been spreading rapidly throughout Europe [8] at 6-20 km annually in the east-west direction. The pollen concentration in Croatia is measured in Zagreb and Osijek, whereas there are around 400 measurement points in Europe [9]. The highest level of ragweed infestation has been recorded on agricultural land, as it is shown in the research [10]. The spread of ragweed within a crop is determined by remote sensing [11]. Remote sensing, global positioning systems (GPS systems), and geographic information systems (GIS) are information technologies [12] with remote sensing being an indispensable method in various scientific fields. Thanks to the development of information technology, its results have been extensively used in numerous areas and a growing body of research [13, 14]. Remote sensing is often used for environmental research and activity monitoring $[15,16]$. It is the science of acquisition of information about an object or phenomenon without maintaining any physical contact. According to $[17,18]$, it is usually performed from landbased, air-based, and satellite-based platforms. Remote sensing increases the capacity of data acquisition as well as the accuracy of the model of infestation and spread [19]. The research [20] stipulates that remote sensing of ragweed is performed on areas as large as 1 ha and bigger. Visual data interpretation, also known as photointerpretation, is the identification and delimitation of the depicted objects. Visual interpretation facilitates an analysis of imagery at every level of categorization, thus enhancing the processing of digital photos. The recognition of the differences among the objects and environment implies a comparison based on one or more basic elements or phenomena in the surveyed environment, as stipulated by $[21,22]$. Furthermore, the spatial information system is used for the acquisition of spatial data that provide descriptive information. Additionally, GPS/GIS provides an accurate acquisition of numerous data on spatial and temporal variability. The accurate information on weed spread on agricultural and other types of land is a prerequisite for efficient weed control. The objective of the research is to show the application of remote sensing in ragweed control on agricultural land. Remote sensing detects both the spread of ragweed and it provides faster and efficient mapping. It was performed from the air using diverse types of cameras with special filters. Then, based on the acquired data, maps were created using a special software. While capturing the images of the ragweed infected agricultural land, illegal waste dumps and other uncultivated areas were surveyed for they are potential sources of ragweed spread. The obtained maps have a significant economic benefit when mapping agricultural land as well as woodland.

\section{MATERIALS AND METHODS}

Remote sensing was performed in co-operation with the company Ciklonizacija Ltd. in the areas of Apatin, Bački Breg, Petrovaradin, Sombor, Titel, and Veternik, Serbia, in 2015 and 2016. Ragweed remote sensing started with classification and monitoring followed by the correction of the classification results by visual interpretation and additional information. The objective of monitoring was to determine the circumstances of the spatial spread of ragweed based on the aerial images. The images can be obtained using helicopters, drones, or airplanes with a mounted modified camera. A Bell Jet Ranger helicopter (Fig 1) captured the RGB images, whereas a DJI Phantom 4 drone (Fig 2) captured the infrared images. Prior to the recording, the areas included in the research where checked. The researched ragweed-infested area must be homogenous, which implies a prominent level of similarity. To achieve proper classification and monitoring, it is necessary to have an 
orthoimage, which is obtained from several images. The images of the surveyed areas were taken with a camera that records within the visible electromagnetic spectrum, whereas some sites were recorded by an NGB camera (Near Infrared, Green, and Blue), which records both in the visible and infrared (IR) part of the spectrum.

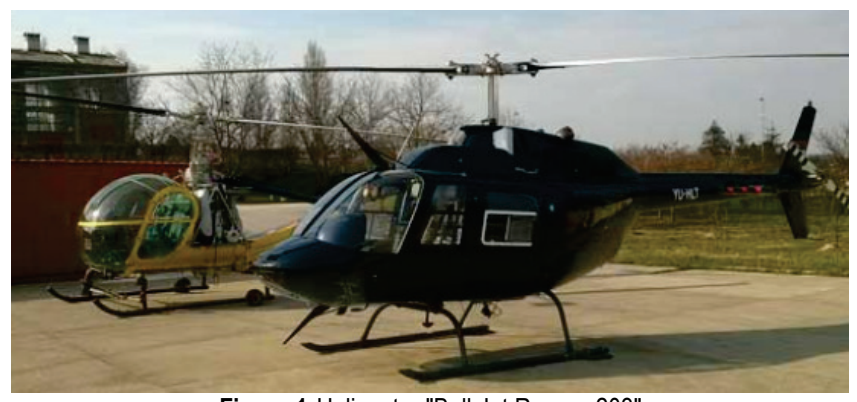

Figure 1 Helicopter "Bell Jet Ranger 203"

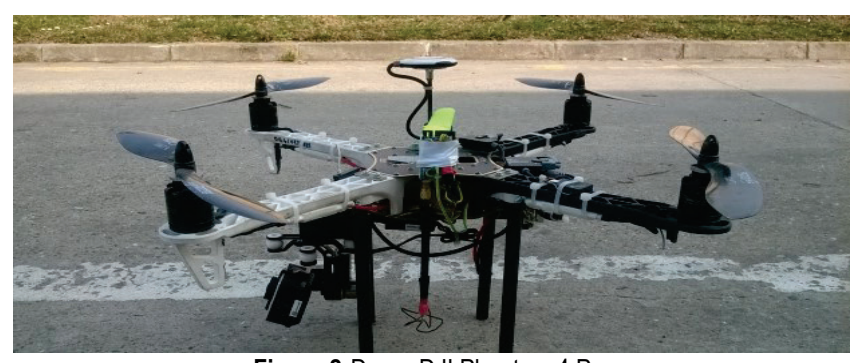

Figure 2 Drone DJI Phantom 4 Pro

Spatial resolution of aerial photos is a key factor. The higher the resolution, the more accurate is both the ragweed classification and the visual interpretation of the acquired images. The accuracy of ragweed spread detection determined by remote sensing is dependent on the season. A higher level of accuracy is achieved in summer, when ragweed retains more water in its leaves compared to other plants. Consequently, its leaves are greener, in which case a higher level of detection accuracy is achieved. Ref. [24] claims that plant pigmentation enables the identification of invasive plants based either on the cryophile content or the unique color of leaves and flowers. The paper shows the classification and monitoring as well as the correction of the classification results created by visual interpretation.
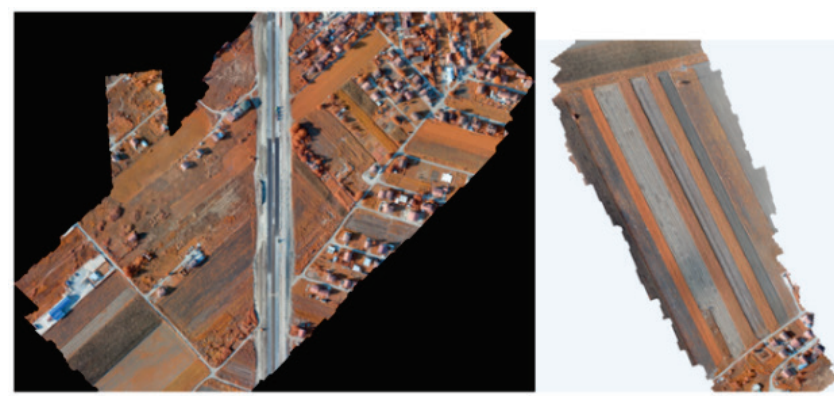

Figure 3 NGB Orthorectified aerial image acquired with an unmanned aerial vehicle

The first step in the classification process is the acquisition of ORTHO images and their subsequent orthorectification (Fig 3). Klisanski breg is the site which was subject to classification and monitoring. The photos were taken on the 14 September 2015 with a camera that records within the visible part of electromagnetic spectrum (Fig 4).

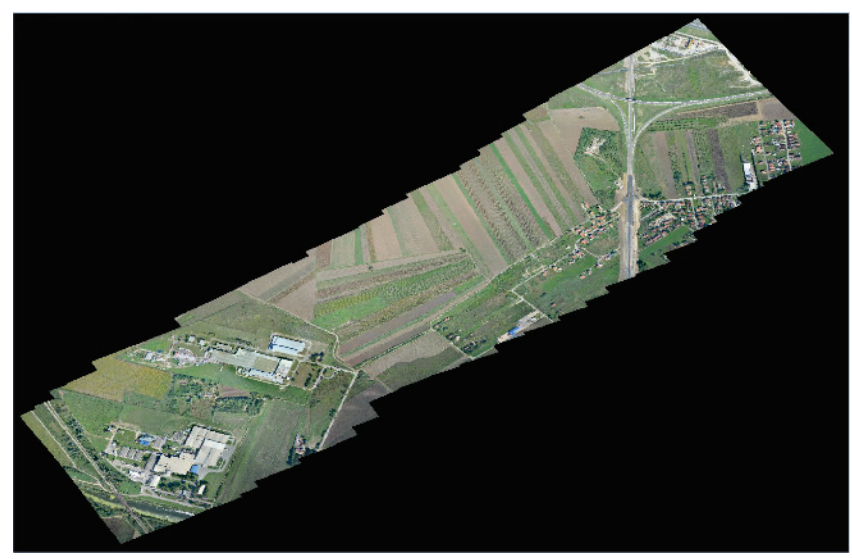

Figure 4 Aerial orthoimage of Klisanski breg

After the acquisition of orthorectified images, the following classes were defined to support the implementation of classification and monitoring (Fig 5): ragweed, fields, path, the surveyed agricultural culture, dry grass, and grass fields.

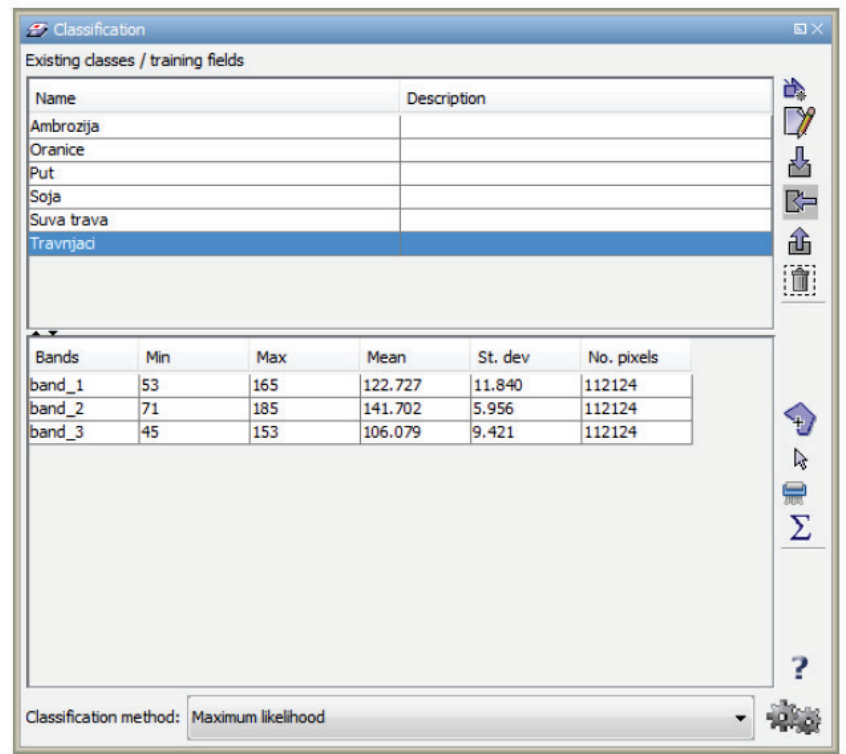

Figure 5 Definition of classes of interest

The contemporary programs Leo Works version 4.0.2.339, and SNAP, version 4.0. were used for image processing, whereas QGIS version 2.18.13 was used for the analysis of spatial data, and finally Agisoft PhotoScan version 1.3.4. was used to join the images. After the imagery acquisition, the classes required for the classification were defined. The next step was the assignment of sites to every defined class in the orthorectified aerial photo.

Fig 6. shows marked areas for every site under surveillance. Upon the selection of research sites for every class, a maximum probability method was applied to the classification with monitoring, which resulted in a thematic 
map (Fig 7). Every class on the thematic map was assigned a certain color. Fig 7. shows the class of ragweed in the left frame marked in red, whereas the singled-out ragweed class marked in green is shown in the same picture on the right side. Following the application of classification with monitoring, a correction of classification results by visual information and additional information was performed.

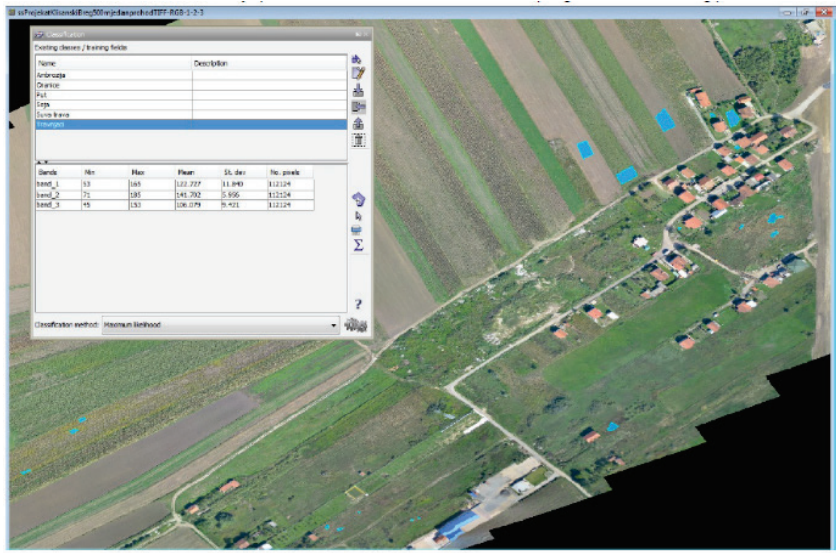

Figure 6 Selection of the surveyed area

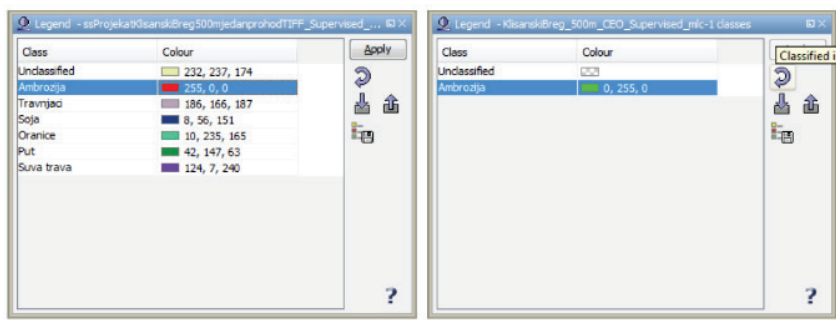

Figure 7 Thematic maps

A proper correction of the classification requires the knowledge of the appearance of certain sites in the orthorectified aerial photo. Information can be extracted from the photos obtained by remote sensing by isolating information based on visual interpretation of the photo or by semi-automatic computer processing. Mapping and land application are some of the ways of information extraction, whereas image classification and parameter calculation are the ways to extract information based on computer image processing. Nowadays, color recognition by the human eye has improved. An image can be analyzed, and information can be extracted in a direct and spontaneous way, or they can stem from a logical conclusion based on evidence. As far as spontaneous recognition is concerned, a farmer is expected to be able to notice and define a certain object faster and easier based on his previous professional experience. However, logical experience requires both previous professional knowledge and experience. The following interpretation elements are required to interpret a photo and to recognize certain objects: tone/color, texture, pattern, form, size, height/altitude, and location/association. The tone can be defined as relative brightness on a black and white photo. Different tones are important for image interpretation. The tone of the depicted object in a photo is directly related to the amount of light reflected against or emitted from the surface. Diverse types of rocks, lands, and vegetation have different tones. Thus, the differences in humidity levels can be discerned as the differences in tones. Consequently, higher humidity levels are discernible as dark gray tones. The differences among colors are related to the spectral features of the surveyed land. The advantage of color differences compared to tone differences results from a higher sensitivity of the human eye to color differences (approx. 10,000 colors) compared to tone sensitivity (approx. 200 tones of gray). Texture refers to the frequency of tonal change. It can be described as rough or fine, smooth or grainy, granulated, smudged, etc. and it is determined by the roughness of the area. Moreover, there is a significant relation between texture and the spatial sensor resolution. Pattern refers to the spatial arrangement of objects, and it implies a characteristic repetition of certain forms and relationships. It can be concentric, radial, etc. The form is a characteristic of many objects. A two-dimensional object projection and its height have an impact on the object depicted in a photo. The form of the object helps to identify it (i.e. paths, railways, agricultural fields). The size of an object can be observed in the absolute or relative sense. The width of a path can be estimated based on the comparison with the commonly known size of a vehicle. Additionally, the differences in heights facilitate the recognition of certain kinds of vegetation, types of buildings, etc.

Finally, location/association refers to the circumstances either on a site or relative to its environment. For example, the woods in mountains are different from those next to seas or rivers. A common use of these elements is crucial for visual interpretation (Fig. 8). Therefore, a standard classification of digital photos which relies solely on color is limited compared to visual interpretation.
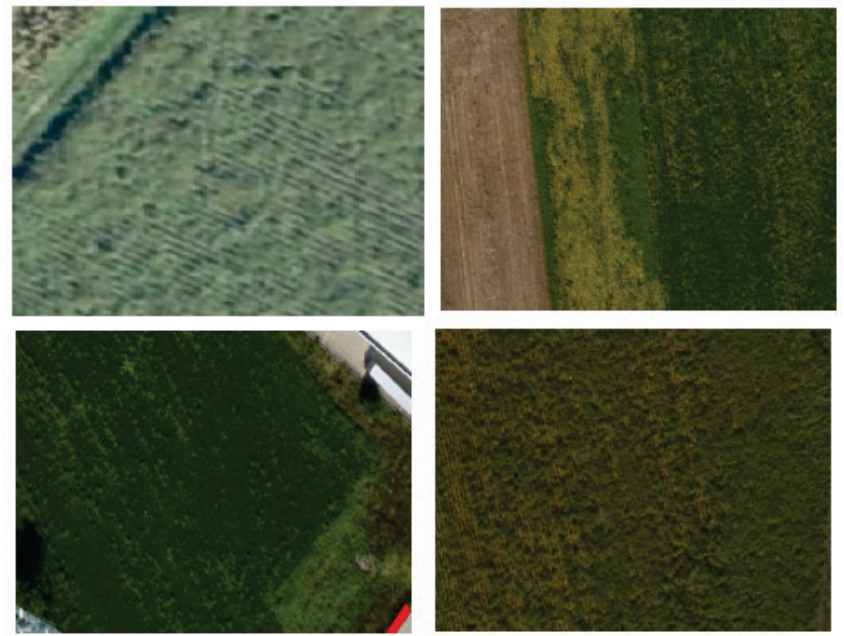

Figure 8 Ragweed within a soy field on the orthorectified image

\section{RESULTS AND DISCUSSION}

Remote sensing of ragweed spread after spraying involved the recording of locations with an NGB camera (NIR, green, and blue) in order to inspect them. The acquired images have revealed the healthy and uncut vegetation in orange, whereas the drying or cut ambrosia has been depicted 
in pale tones of orange and gray color (Fig. 9). Additionally, based on the images, the BNDV index has been created, in which case a color palette has been added as an additional control of the sprayed area (Fig. 10).
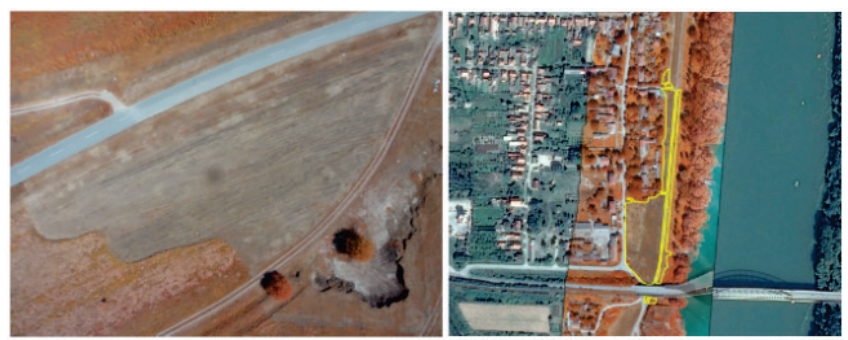

Figure 9 Ragweed within a soy field on the orthorectified image
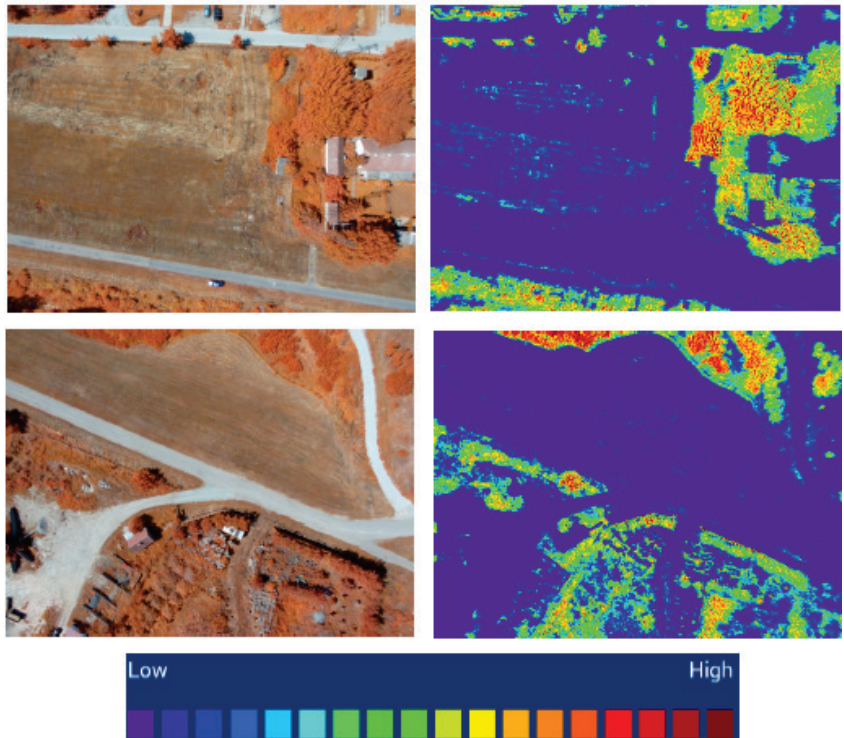

Figure 10 NGB images of cut areas (left) and BNDVI images (right)

The remote sensing of illegal waste dumps was accomplished through visual interpretation of an orthorectified aerial photo (Fig. 11) as well as by applying the NGRDVI index (Normalized Green Red Difference Vegetation Index) (Fig. 12) with the aim of providing potential support in the detection of differences between the vegetation, artificial objects, and unused land shown in the image. NGRDVI $=0$ represents a boundary that helps to distinguish among the land covered with vegetation and other land areas (values of NGRDVI $<0$ ).
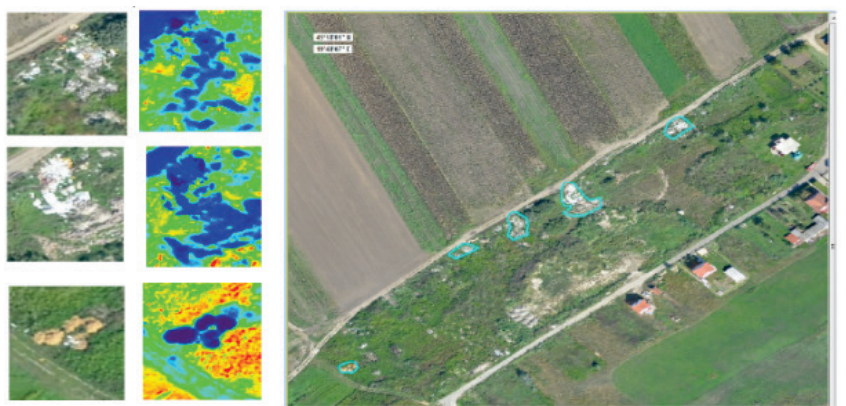

Figure 11 Orthorectified aerial image showing illegal waste dumping areas

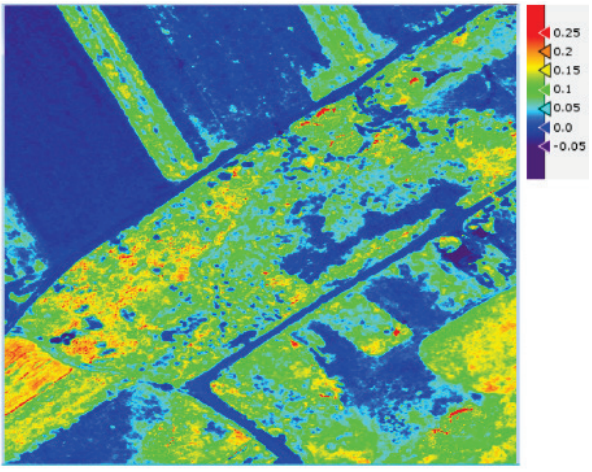

Figure $12 \mathrm{~A}$ Thematic map of the areas with the assigned color palette

\section{CONCLUSIONS}

Based on two years of research, the following conclusions can be drawn:

- By using the remote detection, a rapid, high quality and accurate insight into the spatial distribution of the ambrosia is obtained;

- The data processing makes possible to create precise maps of the ambrosia distribution;

- By repeating this method at certain time intervals we create prerequisites for reducing the occurrence and adverse effects of ambrosia for agricultural cultures and for humans as well;

- Due to the negative effect of ambrosia on agricultural crops and the human health issues (allergies) caused by ambrosia, the costs of remote detection are justified.

\section{REFERENCES}

[1] Chen, H., Chen, L. J., \& Albright, T. P. (2007). Predicting the potential distribution of invasive exotic species using GIS and information-theoretic approaches: A case of ragweed (Ambrosia artemisiifolia L.) distribution in China, Science China Press, China. Chinese Science Bulletin, 52(9), 12231230. https://doi.org/10.1007/s11434-007-0192-2

[2] Jaganjac, M. (2017). Utjecaj porijekla i starosti sjemena na vijabilnost sjemena korovne vrste Ambrosia artemisiifolia, $P h D$ diss., University of Zagreb. Faculty of Agriculture. Department of Plant Pathology.

[3] Lehoczky, É., János, B., \& Gellért, G. (2013). Study on the spread, biomass production, and nutrient content of ragweed with high-precision GNSS and GIS device system. Communications in Soil Science and Plant Analysis, 44(1-4), 535-545. https://doi.org/10.1080/00103624.2013.744157

[4] Nadih, M., Medverec Knežević, Z., Josipović, R., Grgić, I., \& Cvitković, C. (2012). Kretanje peludnih alergena na području Slavonskog Broda za vrijeme polinacijskih sezona 2008.-2010. Arhiv za higijenu rada i toksikologiju, 63(1), 35-39. https://doi.org/10.2478/10004-1254-62-2011-2117

[5] Rašić, S. (2012). Ambrozija (Ambrosia artemisiifolia L.)Agronomski i javno zdrastveni problem na području Baranje. Poljoprivreda, 18(1), 65-66.

[6] https://www.agroklub.com/eko-proizvodnja/ambrozija-korovalergen-i-lijek/26128/ (Accessed: 24.10.2017)

[7] https://biologija.com.hr/modules/AMS/article.php?storyid=21 0 (Accessed: 24.10.2017)

[8] Richter, R., Berger, U., Dullinger, S., Essl, F., Leitner, M., Smith, M., \& Vogl, G. (2013). Spread of invasive ragweed: 
climate change, management and how to reduce allergy costs. Journal of Applied Ecology, 50(6), 1422-1430. https://doi.org/10.1111/1365-2664.12156

[9] Cvitanović, S., Znaor, Lj., Grbić, D., Gudelj, I., Ivančević, Ž., Zekan Lj., \& Perišić, D. (2004). Preosjetljivost na pelud ambrosia elatior u području Županije splitsko-dalmatinske. Godišnji sastanak Hrvatskog društva za alergologiju i kliničku imunologiju Hrvatskog liječničkog zbora, Cavtat.

[10] Ozaslan, C., Onen, H., Farooq, S., Gunal, H., \& Akyol, N. (2016). Common ragweed: an emerging threat for sunflower production and human health in Turkey. Weed Biology and Management, 16(1), 42-55. https://doi.org/10.1111/wbm.12093

[11] Vuković, I., Mesić, M., Bajić, M., Gold, H., Krtalić, A., Bašić, F., Kisić, I., Zgorelec, Ž., \& Sajko, K. (2006). Prostorni raspored zakorovljenosti soje (Glycine hispida) ambrozijom (Ambrosia artemisifolia) pri različitoj gnojidbi dušikom, na temelju obrade digitalnih snimaka. X. kongres Hrvatskog tloznanstvenog društva s međunarodnim sudjelovanjem, Šibenik, Hrvatska, 14-17

[12] Stević, A. (2014). Primjena GIS tehnologije u sustavu precizne poljoprivrede pri sadnji trajnih nasada, $P h D$ diss., Josip Juraj Strossmayer University of Osijek. Faculty of agriculture.

[13] Jurišić, M. \& Plaščak, I. (2009). Geoinformacijski sustavi GIS $u$ poljoprivredi $i$ zaštiti okoliša, Poljoprivedni fakultet $\mathrm{u}$ Osijeku.

[14] Anderson, B. J. (2008). Research in the journal Landscape Ecology, 1987-2005. Landscape Ecology, 23(2), 129-134. https://doi.org/10.1007/s10980-007-9187-2

[15] Gillespie, T. W., Foody, G. M., \& Rocchini, D. (2008). Measuring and modelling biodiversity from space. Progress in Physical Geography: Earth and Environment, 203-221. https://doi.org/10.1177/0309133308093606

[16] Coops, N. C., Wulder, M. A., \& Iwanicka, D. (2009). An environmental domain classification of Canada using Earth observation data for biodiversity assessment. Ecological Informatics, 4, 8-22. https://doi.org/10.1016/j.ecoinf.2008.09.005

[17] http://geoinformatika.uns.ac.rs/index.php/daljinska-detekcijai-obrada-slike/ (Accessed: 24.10.2017)

[18] http://www.nrcan.gc.ca/node/9363 (Accessed: 24.10.2017)

[19] Cohen, W. B. \& Goward, S. N. (2004). Landsat's role in ecological applications of remote sensing. BioScience, 54, 535545. https://doi.org/10.1641/0006-3568(2004)054[0535:LRIEAO]2.0.CO;2

[20] Dezso, B., Fekete, I., Gera, D. A., Giachetta, R., \& László, I. (2012). Object-based image analysis in remote sensing applications using various segmentation techniques. Annales Universitatis Scientiarum Budapestinensis de Rolando Eotvos Nominatae Sectio Computatorica, 37, 103-120.

[21] Oštir, K. (2006). Daljinsko zaznavanje, Založba ZRC, ZRC SAZU, Ljubljana.

[22] Bozja, K. (2010). Vizualna intepretacija letalskih posnetkov v GE Grosuplje, Diplomski rad, Biotehnički fakultet, Univerza v Ljubljani, Ljubljana.

[23] Bažon, I. (2009). Važnost kemijskih ispitivanja tla i biljnog tkiva u uzgoju vinove loze, Završni rad, Sveučilište u Zagrebu, Agronomski fakultet $u$ Zagrebu.

[24] Bradley, Bethany A. (2014). Remote detection of invasive plants: a review of spectral, textural and phenological approaches. Biological Invasions, 16(7), 1411-1425. https://doi.org/10.1007/s10530-013-0578-9
Authors' contacts:

Ivan PLAŠČAK, PhD, Assistant Professor Faculty of Agrobiotechnical Sciences Osijek, Vladimira Preloga 1, 31000 Osijek, Croatia iplascak@pfos.hr

Mladen JURIŠIĆ, PhD, Full Professor Faculty of Agrobiotechnical Sciences Osijek, Vladimira Preloga 1, 31000 Osijek, Croatia mjurisic@pfos.hr

Ante ŠILJEG, PhD, Assistant Professor University in Zadar, Dep. For Geography, Trg kneza Višeslava 9, 23000 Zadar, Croatia asiljeg@unizd.hr

Lazar JEFTIĆ

Ciklonizacija d.o.o.

Trg Svetog Jurja 9, 49216 Desinić, Croatia pr@ciklonizacija.net

Domagoj ZIMMER, MSc, Assistant Faculty of Agrobiotechnical Sciences Osijek, Vladimira Preloga 1, 31000 Osijek, Croatia dzimmer@pfos.hr

Željko BARAČ, MSc, Assistant Faculty of Agrobiotechnical Sciences Osijek, Vladimira Preloga 1, 31000 Osijek, Croatia zbarac@pfos.hr 